\title{
MODELING ASYMMETRIC INFORMATION WARFARE IN THE PRESENCE OF HYPE*
}

\section{O. G. Podlipskaia}

\author{
Moscow Institute of Physics and Technology, Dolgoprudny, Russia \\ $\square$ proncheva@phystech.edu
}

\begin{abstract}
One of the typical situations in information confrontation is that one of the parties has an advantage in the broadcasting resource, while the other party spreads more viral messages. The question arises as to the extent to which these factors can balance each other. In other words, how large should be the advantages of one of the parties in its factor in order to win the information war. The model of information confrontation in society in the presence of excitement is considered. Supporters are believed to be recruited by the two parties by spreading messages through affiliated media. Their supporters participate in participatory propaganda, spreading these messages to other individuals. The model has the form of a system of two nonlinear ordinary differential equations. Numerical experiments have been carried out with the model. Within the framework of the experiments, all parameters were recorded, except for the broadcasting intensity of one party and the intensity of the transmission of messages by the other party during interpersonal communication. The values of the first of these parameters were taken with a certain step, and through numerical experiments. One of these parameters was varied, and the value of the second parameter was determined by a numerical experiment, at which the parties have an equal number of supporters at the end of the confrontation. The ratio between the specified parameters is obtained, at which the given party wins. This relationship is linear.
\end{abstract}

Keywords: information warfare, mathematical modeling, delay-differential equations, numerical experiments.

Introduction. Information warfare being considered, a typical situation is when one of the belligerent parties has the advantage of greater broadcasting resource while the other party's message is more viral. This may happen, for instance, during pandemics when mainstream media broadcast scientifically based information about relevant threats, necessary measures and vaccination, while dissidents spread sensationalist fake information that becomes viral just due to sensationalism. Another example is typical for political life. The government broadcasts widely, but the opposition messages may be more viral.

Both examples share the following features. There are two parties being involved in information warfare. They spread their messages via affiliated mass media and their supporters relay these messages to other individuals. Each individual can either support one of the parties or be neutral. Supporters relay their party's message to other individuals, thus taking part in participatory propaganda (term coined in [1]).

One of the parties has a greater broadcasting resource while the opposing party spreads its message mainly through interpersonal communication still being able to hold a significant number of supporters.

\footnotetext{
* The research was supported by the Russian Foundation for Basic Research (project 20-01-00229).
} 
The question we address in this paper is how much advantage in propaganda broadcasting can balance the opponent's advantage in virality? Roughly speaking, suppose we are playing for party $X$ and our message is relayed by the average supporter to three individuals per unit of time, while the message of party $Y$ is relayed by their average supporter to six individuals. Is it enough for us to have twice more of broadcasting to make the number of supporters even? Or should we mean the difference of these intensities rather than the ratio? To address such questions, we consider a mathematical model of information warfare, in which the intensities of broadcasting and relaying messages through interpersonal communications are taken as given parameters. The equations of the model are solved numerically, thus yielding the winner, that is the party having more supporters than the other at the end of the warfare.

All parameters but two being fixed, manipulating these two allows us to find the sought-for relationship. That is, for a given intensity of relaying the message of party $Y$ we find the intensity of broadcasting of party $X$ that yields the equal number of supporters of both parties at $t \rightarrow \infty$.

This relationship is aimed to be this article's value added to the mathematical theory of information warfare and spread of information in population which has been developing in a range of directions. In terms of the number of papers, the most popular area is probably epidemiological modeling of rumors. The earliest models of rumors [2, 3] were introduced in 1964 and 1973. The model of competing rumors [4] was proposed basing on their approach. Today an extensive literature is devoted to mathematical modeling and empirical research of the dynamics of opinions and informational influence, such as the monograph [5] and articles [6-9]. Neurological model of propaganda battle was developed in $[10,11]$. Relevant empirical papers employ the analysis of statistics of web search requests $[12,13]$ and opinion mining $[14,15]$. Some studies analyze national laws and legal documents in the context of information threats $[16,17]$. The model of this paper is a development of the basic model that was proposed in $[18,19]$ (see also [20]). We also include the hype term in the form different from [21].

Model. Consider the process of information warfare in a population of $N$ individuals. Denote $x(t)$ the number of supporters of party $X$, and $y(t)$ the number of supporters of party $Y$. The model has the form

$$
\begin{gathered}
\frac{d x}{d t}=\left[b_{x}-b_{y}+\frac{c_{x} x(t)}{N}+a \frac{(x(t)-x(t-1))}{N}\right](N-x(t)-y(t)), \\
\frac{d y}{d t}=\left[b_{y}-b_{x}+\frac{c_{y} y(t)}{N}+a \frac{(y(t)-y(t-1))}{N}\right](N-x(t)-y(t)), \\
x(0)=x^{0} ; y(0)=y^{0} .
\end{gathered}
$$

Here a characterizes the significance of hype, as $x(t)-x(t-1)$ is the number of new supporters of party $X$. The greater this number the greater is the hype and therefore the motive for each of $N-x(t)-y(t)$ nonattached individuals. Note that in [22] the hype term had the form $d x / d t$ rather than $x(t)-x(t-1)$. Further, $b_{x}, b_{y}$ are intensities of broadcasting by parties $X$ and $Y$, so that $b_{x}-b_{y}$ is the advantage of party $X$ over party $Y$. It is applied to the same number $N-x(t)-y(t)$ 
individuals who do not belong with any party. At last, $c_{x}, c_{y}$ are intensities of relaying messages through interpersonal communication and $x(t)(N-x(t)-y(t))$ is the incidence of meetings of supporters of party $\mathrm{X}$ and neutral individuals.

For our numerical experiments, we assume that $b_{x}>b_{y}$ and $c_{x}<c_{y}$. That is, the party $\mathrm{X}$ has a greater broadcasting resource while the message of party $\mathrm{Y}$ is more viral. In what follows we fix the parameters $a, b_{y}, c_{x}$.

Numerical experiments. A number of numerical experiments was conducted. Here we lay out one of them. Let $a=0.1, b_{y}=c_{x}=1, N=10$. The initial condition has the form $x(0)=y(0)=2$.

For values $c_{y}>c_{x}=1$ we solved the equations numerically with various values of $b_{x}$ to determine the one under which the parties have equal number of supporters at the end of the warfare, that is $x(t)=y(t)=5$ for large $t$. The results are shown in Table 1 . The function $b_{x}\left(c_{y}\right)$ appeared to be linear.

In other conducted experiments this function also was linear.

Table 1. The results of the numerical experiment

\begin{tabular}{llllllll}
$c_{y}$ & $b_{x}$ & $c_{y}$ & $b_{x}$ & $c_{y}$ & $b_{x}$ & $c_{y}$ & $b_{x}$ \\
\hline 1 & 0 & 1,5 & 0,077 & 2 & 0,1534 & 2,5 & 0,2296 \\
\hline 1,05 & 0,0078 & 1,55 & 0,0846 & 2,05 & 0,161 & 2,55 & 0,2372 \\
1,1 & 0,0154 & 1,6 & 0,0922 & 2,1 & 0,1686 & 2,6 & 0,245 \\
1,15 & 0,0232 & 1,65 & 0,0998 & 2,15 & 0,1762 & 2,65 & 0,2526 \\
1,2 & 0,0308 & 1,7 & 0,1076 & 2,2 & 0,184 & 2,7 & 0,2602 \\
1,25 & 0,0386 & 1,75 & 0,1152 & 2,25 & 0,1916 & 2,75 & 0,2678 \\
1,3 & 0,0462 & 1,8 & 0,1228 & 2,3 & 0,1992 & 2,8 & 0,2754 \\
1,35 & 0,054 & 1,85 & 0,1304 & 2,35 & 0,2068 & 2,85 & 0,283 \\
1,4 & 0,0616 & 1,9 & 0,1382 & 2,4 & 0,2144 & 2,9 & 0,2906 \\
1,45 & 0,0692 & 1,95 & 0,1458 & 2,45 & 0,222 & 2,95 & 0,2982
\end{tabular}

Conclusion. The main finding is quite unexpected. Clearly, being a system of nonlinear delaydifferential equations, the model cannot be solved analytically. Still, the numerical experiments show the linear relationship between parameters. That is, the party $\mathrm{X}$ wins if $b_{x}>k_{1} c_{y}+k_{2}$, where $k_{1}, k_{2}$ depend on the parameters and unlikely to have analytical expression.

\section{References}

1. Wanless, A. and Berk, M., 2019. The audience is the amplifier: Participatory propaganda. The Sage Handbook of Propaganda. Sage: London. P. 85-104.

2. Daley, D.J., Kendall, D.G.: Stochastic rumors // Journal of the Institute of Mathematics and its Applications, 1, 42-55 (1964).

3. Maki, D.P., Thompson, M.: Mathematical Models and Applications, Prentice-Hall, Englewood Cliffs, NJ, USA (1973)

4. Osei, G.K., Thompson, J.W.: The supersession of one rumour by another // J. of Applied Probability, 14(1), 127-134 (1977). 
5. A.G. Chkhartishvili, D.A. Gubanov, D.A. Novikov. Social Networks: Models of information influence, control and confrontation. Cham, Switzerland: Springer International Publishing, 2019. - $158 \mathrm{c}$. DOI: $10.1007 / 978-3-030-05429-8$.

6. D. Gubanov, I. Petrov. Multidimensional Model of Opinion Polarization in Social Networks // 2019 Twelfth International Conference "Management of large-scale system development" (MLSD). Moscow, Russia: IEEE, 2019. C. 1-4. DOI: 10.1109/MLSD.2019.8910967.

7. A.G. Chartishvili, I.V. Kozitsin, V.L. Goiko, E.R. Saifulin. On an Approach to Measure the Level of Polarization of Individuals' Opinions // 2019 Twelfth Inter-national Conference "Management of large-scale system development" (MLSD), Moscow, Russia, 2019, pp. 1-5, doi: 10.1109/MLSD.2019.8911015.

8. I.V. Kozitsin, A.M. Marchenko, V.L. Goiko, R.V. Palkin. Symmetric Convex Mechanism of Opinion Formation Predicts Directions of Users' Opinions Trajec-tories // 2019 Twelfth International Conference "Management of large-scale sys-tem development" (MLSD), Moscow, Russia, 2019, pp. 1-5, doi: 10.1109/MLSD.2019.8911064.

9. A.P. Petrov, S.A. Lebedev. Online Political Flashmob: the Case of 632305222316434 // Computational mathematics and information technologies. - 2019. — No 1. - P. 17-28. doi: 10.23947/25878999-2019-1-1-17-28.

10. Petrov A. P., Maslov A. I., Tsaplin N. A. Modeling Position Selection by In-dividuals during Information Warfare in Society // Mathematical Models and Computer Simulations, 2016, Vol. 8, No. 4, pp. 401-408, doi:10.1134/S2070048216040141.

11. Petrov A., Proncheva O. (2018) Modeling Propaganda Battle: Decision-Making, Homophily, and Echo Chambers. In: Artificial Intelligence and Natural Language. AINL 2018. Communications in Computer and Information Science, vol 930. Springer. P. 197-209. doi: 10.1007/978-3-030-01204-5_19

12. A. Boldyreva, O. Sobolevskiy, M. Alexandrov, V. Danilova. Creating collec-tions of descriptors of events and processes based on Internet queries // 14-th Mexican Intern. Conf. on Artif. Intell. (MICAI-2016), Springer Cham, LNAI, 2016, vol. 10061 (chapter 26), 2016. pp. 303-314, https://doi.org/10.1007/978-3-31962434-1_26.

13. A. Boldyreva, M. Alexandrov, O. Koshulko, O. Sobolevskiy. Queries to In-ternet as a tool for analysis of the regional police work and forecast of the crimes in regions // 14-th Mexican Intern. Conf. on Artif. Intell. (MICAI-2016), Springer Cham, LNAI, vol. 10061 (chapter 25), 2016. pp. 290-302, https://link.springer.com/chapter/10.1007/978-3-319-62434-1_25.

14. L. Akhtyamova, M. Alexandrov, J. Cardiff, O. Koshulko. Opinion Mining on Small and Noisy Samples of Health-related Texts. // Advances in Intelligent Sys-tems and Computing III (Proc. of CSIT-2018), Springer, AISC, 2019, vol. 871, p.1-12.

15. L. Akhtyamova, M., J. Cardiff. LM-Based Word Embeddings Improve Bio-medical Named Entity Recognition: A Detailed Analysis. // Lecture Notes in Computer Science, vol 12108. Springer, Cham, doi: 10.1007/978-3-030-45385-5_56.

16. Pronchev G.B., Shisharina E.V., Proncheva N.G. Cyber threats for modern Russia in the context of the coronavirus pandemic // Political Science Issues. Vol. 11. 1(48-50). P.26-34. DOI: 10.35775/PSI.2021.48.1.003.

17. Pronchev, G.B., Mikhailov, A.P., Lyubimov, A.P. and Solovyev, A.A., 2020. Particularities of the Internet-based virtual social environments within the context of information warfare. EurAsian Journal of BioSciences, 14(2), pp.3731-3739.

18. A.A. Samarskii, A.P. Mikhailov. Principles of Mathematical Modelling: Ide-as, Methods, Examples. 2001. Taylor and Francis Group.

19. Mikhailov A. P., Marevtseva N. A. Models of information struggle // Math. Models Comput. Simul., Vol. 4, No. 3 (2012), P. 251-259.

20. Mikhailov A. P., Petrov A. P., Marevtseva N. A., Tretiakova I. V. Develop-ment of a Model of Information Dissemination in Society // Mathematical Models and Computer Simulations, 2014, Vol. 6, No. 5, pp. 535-541, 2014.

21. A.P. Mikhailov, L.F. Yukhno. The formulation and preliminary study of the model of the hype dissemination of information in society // Computational mathematics and information technologies. - 2019. — No 2. P. 76-82. doi: 10.23947/2587-8999-2019-2-2-76-82. 


\section{Author:}

Olga Podlipskaia, Moscow Institute of Physics and Technology, Dolgoprudny, Russia, Department of Higher Mathematics, Associate Professor.

Address: 9 Institutskiy per., Dolgoprudny, Moscow Region, 141701, Russian Federation. e-mail: proncheva@phystech.edu. 


\section{МОДЕЛИРОВАНИЕ НЕСИММЕТРИЧНОГО ИНФОРМАЦИОННОГО ПРОТИВОБОРСТВА ПРИ НАЛИЧИИ АЖИОТАЖА*}

\section{О. Г. Подлипская}

Московский физико-технический институт (национальный исследовательский университет), г. Долгопрудный, Московская область, Российская Федерация

$\square$ proncheva@phystech.edu

Одна из типовых ситуаций при информационном противоборстве состоит в том, что одна из партий обладает преимуществом в ресурсе вещания, а другая партия распространяет более вирусные сообщения. Возникает вопрос о том, в какой мере эти факторы могут уравновешивать друг друга. Другими словами, насколько большим должно быть преимуществ одной из сторон в своем факторе, чтобы одержать победу в информационном противоборстве. Метод. Рассматривается модель информационного противоборства в социуме при наличии ажиотажа. Предполагается, что две партии вербуют сторонников, распространяя сообщения через аффилированные средства массовой информации. Их сторонники участвуют в партиципаторной пропаганде, распространяя эти сообщения среди других индивидов. Модель имеет вид системы двух нелинейных обыкновенных дифференциальных уравнений. С моделью проведены численные эксперименты. В рамках экспериментов фиксировались все параметры, кроме интенсивности вещания одной партии и интенсивности передачи сообщений другой партии при межличностной коммуникации. Значения первого из этих параметров перебирались с определенным шагом, и путем численных экспериментов. Один из этих параметров варьировался, и путем численного эксперимента определялось значение второго параметра, при котором партии имеют равное количество сторонников на конец противоборства. Получено соотношение между указанными параметрами, при котором побеждает данная партия. Это соотношение носит линейный характер.

Ключевые слова: информационное противоборство, математическое моделирование, дифференциальные уравнения, численные эксперименты

\section{Авторы:}

Ольга Геннадьевна Подлипская, Московский физико-технический институт (национальный исследовательский университет), г. Долгопрудный, Московская область, Российская Федерация. Кафедра высшей математики, доцент.

Контактная информация: 141701, Московская область, г. Долгопрудный, Институтский пер., 9.

e-mail: proncheva@phystech.edu.

\footnotetext{
* Исследование выполнено при финансовой поддержке РФФИ в рамках научного проекта № 20-01-00229.
} 